\title{
ANOBOTHRUS AMOUROUXI SP. NOV., A NEW SPECIES OF Ampharetidae (Polychaeta) from the Capbreton Canyon (Bay of Biscay, ne atlantic Ocean)
}

\author{
Paulo Bonifacio ${ }^{1,2}$, Nicolas Lavesque ${ }^{1}$, Guy \\ BACHELET $^{1}$ AND JULIO PARAPAR ${ }^{3}$
}

\footnotetext{
${ }^{1}$ Université de Bordeaux, CNRS, EPOC UMR 5805, Station Marine d'Arcachon, 2 rue du Professeur Jolyet, 33120 Arcachon, France

${ }^{2}$ Sorbonne Universités, UPMC Université Paris 06, CNRS, LECOB, UMR 8222, Observatoire Océanologique, 66650 Banyuls-sur-Mer, France

${ }^{3}$ Departamento de Bioloxía Animal, Bioloxía Vexetal e Ecoloxía, Facultade de Ciencias, Campus da Zapateira, Universidade da Coruña, 10 Rúa Alejandro de la Sota 1, 15008 A Coruña, Spain
}

Corresponding author: P. Bonifácio, bonif@me.com

Accepted in Journal of the Marine Biological Association of the UK. 
A new species of Ampharetidae, Anobothrus amourouxi sp. nov., has been identified from bathyal depths of the Capbreton Canyon, Bay of Biscay (NE Atlantic Ocean). This new species is characterized by inner branchiae with transversal ciliated ridges, notochaetae from modified eighth thoracic unciniger with hirsute tips, uncini from thoracic unciniger with 6-7 teeth in lateral view arranged in two vertical rows in frontal view, fused segments II+III with paleae from SII and reduced notopodia without chaetae from SIII. An identification key for all hitherto described species of the genus Anobothrus is provided.

Keywords: Polychaeta, Ampharetidae, Anobothrus, taxonomy, new species, Bay of Biscay, Capbreton Canyon 


\section{INTRODUCTION}

Members of the Family Ampharetidae (Annelida: Polychaeta) are widely distributed from intertidal to abyssal depths and are common in deep-sea environments like plains, hot vents or cold seeps (Böggemann, 2009; Reuscher et al., 2009; Aguirrezabalaga \& Parapar, 2014). According to Jirkov (2011), this family includes more than 200 valid species distributed in two subfamilies: Ampharetinae Malmgren, 1866 and Melinnae Chamberlin, 1919. The taxonomy of ampharetids is complex and recently the number of genera was proposed to be strongly reduced from 90 to 24 (Jirkov, 2011). The genus Anobothrus is one of the most speciose with 18 species currently considered valid, 10 of them described between 2008 and 2014 (Jirkov, 2008; Schüller, 2008; Reuscher et al., 2009; Imajima et al., 2013; Schüller \& Jirkov, 2013).

The first studies concerning the deep-sea macrofauna of the Bay of Biscay started in the $19^{\text {th }}$ century and several expeditions were conducted in the 1970 s (Laubier, 1985). Since the 1990s, several new species of Polychaeta have been described in the Capbreton Canyon following new oceanographic cruises from 1987 to 1990 (San Martín et al., 1996; Nuñez et al., 2000; Aguirrezabalaga et al., 2001, 2002; Aguirrezabalaga \& Ceberio, 2003, 2005a, 2005b, 2006; Aguirrezabalaga \& Carrera-Parra, 2006; Aguirrezabalaga \& Gil, 2009; Aguirrezabalaga \& Parapar, 2014). The Capbreton Canyon is situated in the southeast of the Bay of Biscay, beginning at $250 \mathrm{~m}$ from the coastline, in front of Hossegor city. It extends through $300 \mathrm{~km}$ before ending on the abyssal plain at $3500 \mathrm{~m}$ depth (Gaudin et al., 2006; Mazières et al., 2014). Currently disconnected from the Adour River, the canyon continues to be affected by its plume during $20 \%$ of the year (Petus et al., 2014). The Capbreton Canyon separates the northern Aquitanian shelf from the narrower southern Cantabrian platform (Pascual et al., 2004).

The main purpose of the BIOMIN project was to study the in situ impact of the biological diversity on the mineralization of the organic matter at the water-sediment interface. This study took place close to three river mouths: Rhône River (Gulf of Lions, Mediterranean Sea), Gironde Estuary and Adour River (Bay of Biscay, Atlantic Ocean). During this project a new species of Anobothrus was discovered in the 
Capbreton Canyon. The present paper provides the description of this species as well as a key for world-wide hitherto described species of this genus.

\section{Materials And Methods}

The third cruise of the BIOMIN project (BIOMIN-3) took place on board of the RV Côtes de la Manche in July 2012 in the Capbreton Canyon. Macrofauna was sampled at 5 stations situated between 108 to $735 \mathrm{~m}$ depth and between 18 and 52 km off the Adour River (Figure 1). At each station, samples were collected using a Hamon grab (3 replicates of $0.25 \mathrm{~m}^{2}$ ) and an Oktopus® $\mathrm{GmbH}$ MC 6 multicorer (9 replicates of $0.007 \mathrm{~m}^{2}$ ).
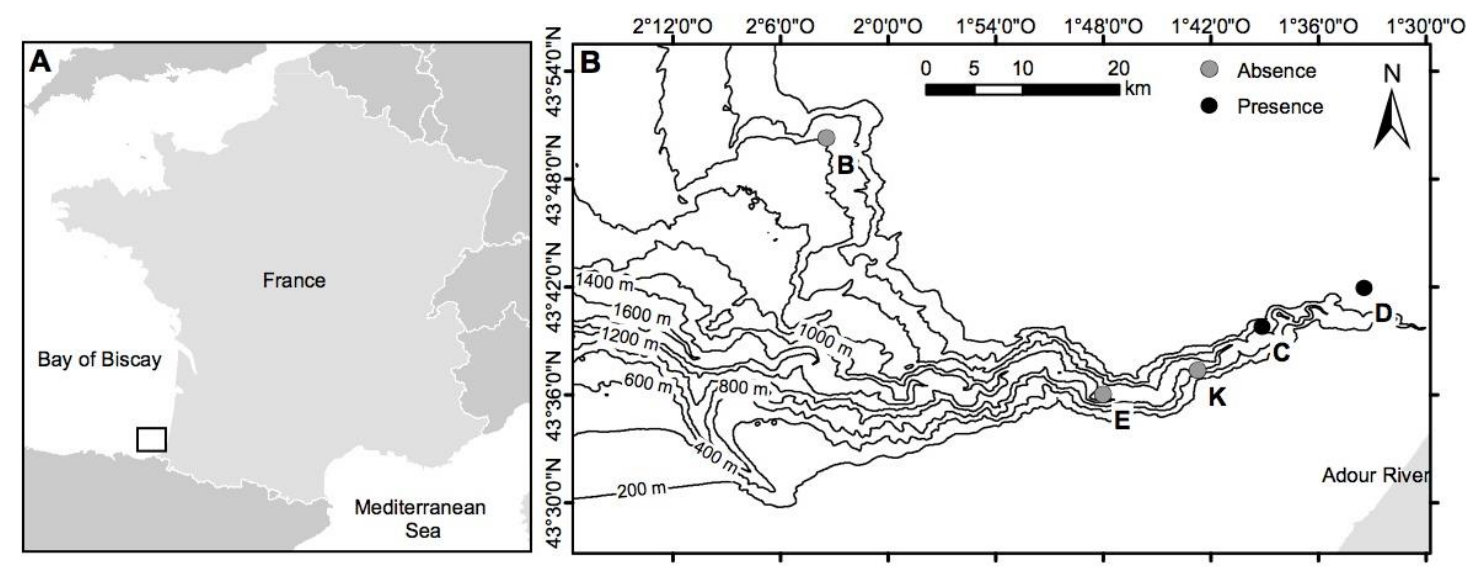

Figure 1. BIOMIN-3 cruise sampling stations in the Capbreton Canyon showing those with presence (black circles) and absence (grey circles) of Anobothrus amourouxi sp. nov.

Samples were sieved through a $1 \mathrm{~mm}$ mesh and the remaining fraction was immediately fixed in $5 \%$ buffered formalin. Back to the laboratory, organisms were sorted, identified to the lowest taxonomic level (in most cases to the species level) and counted.

Specimens of the new Anobothrus species were examined under a Nikon SMZ 1500 stereomicroscope and a Nikon Eclipse E400 microscope, and photographed with a Nikon DS-Fi 2 camera. Some specimens were figured with a 
Wacom Intuos 5 tablet and Adobe Illustrator software. Length and width were measured with the NIS Elements Analysis software. Specimen used for examination with Scanning Electron Microscopy (SEM) was prepared by critical point drying, covered with gold and examined and photographed at the Servicios de Apoio á Investigación-SAI (Universidade da Coruña-UDC, Spain).

Type specimens were deposited in the Muséum National d'Histoire Naturelle (MNHN) (Paris, France) and Museo Nacional de Ciencias Naturales (MNCN) (Madrid, Spain). Additional non-type specimens were deposited in the Arcachon Marine Station.

Abbreviations used in the text: $S=$ segment; $T S=$ thoracic segment; $T C=$ thoracic chaetiger; $\mathrm{TU}=$ thoracic unciniger; $\mathrm{AU}=$ abdominal unciniger .

3 RESULTS

\author{
SYSTEMATICS \\ Family AMPHARETIDAE Malmgren, 1866 \\ Subfamily AMPHARETINAE Malmgren, 1866 \\ Genus Anobothrus Levinsen, 1884
}

Type species: Ampharete gracilis Malmgren, 1866

Synonyms: Anobothrella Hartman, 1967: 155-156; Melythasides Desbruyères, 1978: 232-235; Sosanides Hartmann-Schröder, 1965: 243-246.

\title{
GENERIC DIAGNOSIS (EMENDED)
}

Prostomium trilobed, Ampharete-type, without glandular ridges. Buccal tentacles papillated or smooth. SII and SIII fused. Three to four pairs of branchiae (smooth or with transversal ciliated ridges or papillated), 3 pairs forming transversal 
row with or without gap arising from fused SII+III to SIV and the fourth pair, if present, situated behind this row, arising from SV. Notochaetae in fused SII+III originating from SII or SIII, or both. If present, notochaetae originating from SII varying in size from regular size to strongly enlarged (paleae). If present, notochaetae originating from SIII varying from reduced to regular size. If present, a pair of nephridrial papillae is situated in SIV behind innermost pair of branchiae or behind some anterior notopodia. Sixteen to seventeen TS. Thirteen to fifteen TC starting at SIII-IV. Eleven or twelve TU starting at SVI. Notopodial cirri absent. Circular whitish band in TU1, TU2 or TU3. Fourth-, fifth- or sixth-to-last thoracic unciniger with one or combined modifications: elevated notopodia and/or modified notochaeta and/or dorsal ridge. First two AU of thoracic type. Number of AU generally constant for each species. Abdominal rudimentary notopodia absent.

\section{REMARKS}

This emended generic diagnosis combines the emended diagnosis proposed by Schüller \& Jirkov (2013) and Imajima et al. (2013) which in turn combine previous proposals by Jirkov (2008) and Reuscher et al. (2009). Here we add the presence of transversal ciliated ridges on branchiae as an additional morphological character in the genus which should be taken into account in species descriptions. 
(Figures 2-4)

TYPE MATERIAL

Holotype: $\mathrm{MNHN}-1561$, incomplete specimen (broken at $9^{\text {th }} \mathrm{AU}$ ), one branchial filament lacking and two filaments deciduous, $2.57 \mathrm{~mm}$ long and $1.02 \mathrm{~mm}$ wide, station C1-INCUB (multicorer) (43³9'48"N, 01³9'09"W), 364 m depth, 7 July 2012.

Paratypes: MNHN-1562, complete specimen, all branchiae missing, $12.5 \mathrm{~mm}$ long and $1.5 \mathrm{~mm}$ wide, station C4-MFC (multicorer) (43⒊ $39^{\prime} 48^{\prime \prime} \mathrm{N}, 01^{\circ} 39^{\prime} 09^{\prime \prime} \mathrm{W}$ ), $364 \mathrm{~m}$ depth, 16 July 2012; MNHN-1563, four specimens (two complete), 10.3-13.9 mm long and 1.1-1.3 mm wide, all without branchiae, two specimens with oocytes in body cavity, station D ( 1 specimen collected with Hamon grab, 3 specimens with multicorer) $\left(43^{\circ} 42^{\prime} 00^{\prime \prime} \mathrm{N}, 01^{\circ} 33^{\prime} 27^{\prime \prime W}\right), 108 \mathrm{~m}$ depth, 7 and 12 July 2012; MNCN16.01/16069, complete specimen, three branchial filaments lacking, $6.63 \mathrm{~mm}$ long and $0.63 \mathrm{~mm}$ wide, station C1-INCUB (multicorer) (43⒊'48" $\left.\mathrm{N}, 01^{\circ} 39^{\prime} 09^{\prime \prime} \mathrm{W}\right), 364 \mathrm{~m}$ depth, 7 July 2012; MNCN-16.01/16070, 2 branchiae in a STUB for SEM of the paratype MNCN-16.01/16069; MNCN-16.01/16071, complete specimen in SEM stub (broken at $2^{\text {nd }} \mathrm{AU}$ ), all branchiae missing, $8.6 \mathrm{~mm}$ long and $1.0 \mathrm{~mm}$ wide, station $\mathrm{C} 1$ -

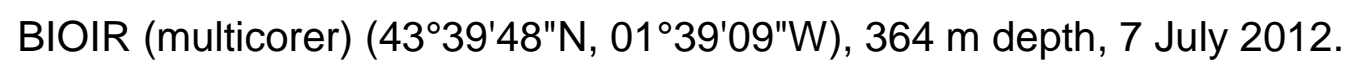

AdDITIONAL MATERIAL

Six specimens (one complete, $12.5 \mathrm{~mm}$ long and $1.5 \mathrm{~mm}$ wide), all without branchiae, one specimen with ventral groove, station C (1 specimen collected with

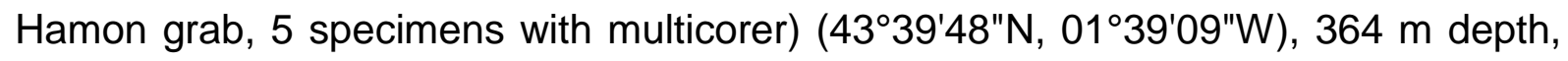
7, 12 and 16 July 2012.

DIAGNOSIS

Inner branchiae with transversal ciliated ridges, other ones smooth. Only modified TU8 provided notochaetae with hirsute tips. Uncini from TU1 with 6-7 teeth 
in lateral view arranged in two vertical rows in frontal view. Uncini from AU3 with 4-5 teeth in lateral view arranged in three vertical rows in frontal view. SII+III fused with paleae from SII but with reduced notopodia without chaetae from SIII. 15 TC, 12 TU and $12 \mathrm{AU}$.

\section{DESCRIPTION (BASED ON HOLOTYPE AND PARATYPES)}

Prostomium trilobed and anteriorly rounded, Ampharete-type, without eyespots. Buccal tentacles apparently smooth (Figure 3B).

Four pairs of long, gradually tapering, cirriform branchiae (Figures 2A, D). No gap between groups of branchiae. First three pairs of branchiophores arranged in a transversal line (inner, middle and outer pairs), forming a high fold, originating from fused SII+III. Fourth pair situated behind between inner and middle pairs, originating from SV (Figure 2D). Diameter of all branchiophores approximately equal. Middle and outer pairs of branchiae with branchiostyles longer and thicker than inner and posterior pairs (Figure 2C). Outer pair longer than remaining ones (Figure 2B). Middle, outer and fourth pairs of branchiae with smooth branchiostyles. Branchiostyles of inner pair of branchiae with tufts of cilia arranged in rows forming transversal ciliated ridges (visible in stereomicroscope) along the whole ventral side of the branchiostyle (Figures 4C, D). All branchiostyles presenting minuscule ciliated buttons (visible only under SEM) along their entire surface (Figures 4E, F). Right branchiostyle of inner pair thicker and longer than the left one. Fourth (posterior) pair of branchiae with thinnest and shortest branchiostyle.

One pair of nephridial papillae, not separated by gap, situated behind the base of innermost pair of branchiae (Figure 2D). Additional pairs of nephridial papillae present behind notopodia of TU1 and TU2 (visible under SEM, Figure 3D).

Fused SII+III with 12-16 gradually tapering paleae, longer and larger than the best-developed notochaetae (Figures 2A, D; 3A) from SII. The longest paleae surpassing the prostomium in lateral view. Fused SII+III (Figures 2A; 3A) with reduced notopodia, rounded in shape, hardly visible under the stereomicroscope, located behind the paleae, without chaetae, presenting a row of pores (Figure $3 \mathbf{C}$ ) 
from SIII. From SIV (TC2) notopodia well developed with rounded to elongate lobes and well developed notochaetae. Seventeen TS and 15 TC. Twelve TU. TU3 with an anterior whitish band (Figure 2A). Fifth-to-last TU (TC11, TU8) with slightly elevated notopodia connected by a pronounced dorsal ridge (Figures 2A; 3E, F), sometimes as high as notopodial lobe (Anobothrus-type).

Abdomen with $12 \mathrm{AU}$. Neuropodia of first two abdominal uncinigers (AU1-2) of thoracic type (tori instead of pinnules; Figure 2A). Neuropodial lobe forming pinnules from AU3 to posterior end. Rudimentary notopodia and neuropodial cirri absent.

Notochaetae bilimbate. First two thoracic chaetigers (SIV-V; TC1-2) with 3-4 short notochaetae; subsequent chaetigers with 5 long and 4 short notochaetae. Notochaeta longer than notopodial lobe in TU. Notochaetae from modified TU8 with hirsute tips (Figures 2F; 4A). TU1 with 38-48 uncini, pectinate, with 6-7 teeth in lateral view, arranged in two vertical rows in frontal view (Figures 2G; 4B). AU3 with 25-35 uncini, situated in marginal position of neuropodial pinnule, pectinate, with 4-5 teeth in lateral view (Figure $\mathbf{2 H}$ ), arranged in three vertical rows in frontal view.

Pygidium with terminal anus, without lateral papillae but with 3-5 dorsal minute folds (Figure 2E).

\section{REMARKS}

Anobothrus amourouxi sp. nov. is similar to A. antarctica Monro, 1939, A. glandularis (Hartmann-Schröder, 1965), A. mironovi Jirkov, 2008, A. paleaodiscus Schüller \& Jirkov, 2013 and $A$. patersoni Jirkov, 2008 because they share the following characters: presence of paleae in fused SII+III from SII, four pairs of branchiae, circular band at TU3, 12 TU, modified fifth-to-last TU (TU8) and 12 AU. These species can be separated into two groups based on the presence or absence of notochaetae with hirsute tips at TU8: Group 1: A. paleaodiscus, A. patersoni and A. mironovi with smooth tips, and Group 2: A. amourouxi sp. nov., A. antarctica and A. glandularis with notochaetae with hirsute tips (but only in TU8). However, A. amourouxi sp. nov. and $A$. antarctica differ from $A$. glandularis for having both 15 TC and ciliated or papillated branchiae instead of 14 TC and smooth branchiae. 
Moreover, $A$. antarctica differs from $A$. amourouxi sp. nov. by presenting all branchiostyles papillated, from sparse to densely papillated (shaggy), while $A$. amourouxi sp. nov. presents only the inner pair provided with transversal ciliated ridges. Furthermore, $A$. antarctica has uncini from TU1 with 4-5 teeth, a large pair of nephridial papillae, and fused SII+III provided with notochaetae from SIII, while $A$. amourouxi sp. nov. has uncini from TU1 with 6-7 teeth, two groups of nephridial papillae, fused SII+III with reduced notopodia and without notochaetae from SIII. Indeed, in A. amourouxi sp. nov. the reduced notopodia from SIII at fused SII-III presents a row of pores instead of chaetae, a character also observed by Aguirrezabalaga \& Parapar (2014: their figure 7E). These pores might be related to chaetae formation.

Although Imajima et al. (2013) suggested that the presence of transversal ciliated ridges on branchiae were related to the size of specimens, this could not be verified in $A$. amourouxi sp. nov. because the two biggest specimens (mature) lost their branchiae. However, no variation linked to age was observed for the other characters described here.

The Anobothrus species reported in the Northeast Atlantic waters are $A$. gracilis (Malmgren, 1866) and A. patersoni Jirkov, 2008. A. gracilis is a species described from Swedish coasts and has a wide distribution in the Arctic Ocean, North Atlantic Ocean (Iceland to Swedish West coast), and Northwest Pacific Ocean (Jirkov, 2008, 2011; Parapar et al., 2014). A. patersoni is an exclusively abyssal species (3260$8292 \mathrm{~m}$ depth) described from North Pacific (Japan) but recorded also in the North Atlantic (Jirkov, 2008). In the Capbreton Canyon, Rallo et al. (1993) found a single specimen of $A$. gracilis between $358-410 \mathrm{~m}$, and two incomplete specimens of Anobothrus aff. gracilis were also reported by Aguirrezabalaga \& Parapar (2014), between 624-652 $\mathrm{m}$ depth. These records should be taken with caution as incomplete specimens may induce wrong identifications. These specimens might belong to $A$. amourouxi sp. nov. because $A$. gracilis share with the new species the possession of 15 TC, fused SII+III with reduced TC without notochaetae from SIII, 12 TU and circular band in TU3. 


\section{ETYMOLOGY}

This species is dedicated to Dr. Jean-Michel Amouroux (Laboratoire Arago, Observatoire Océanologique de Banyuls-sur-Mer, France) for his friendship and many contributions to French benthic research.

\section{DISTRIBUTION}

Specimens of the new species were collected in the Capbreton Canyon muddy bottoms, between 108 and $364 \mathrm{~m}$ depth. In the same area Rallo et al. (1993) and Aguirrezabalaga \& Parapar (2014) reported Anobothrus gracilis at 358-410 m depth and Anobothrus aff. gracilis at 624-652 m depth, respectively. 


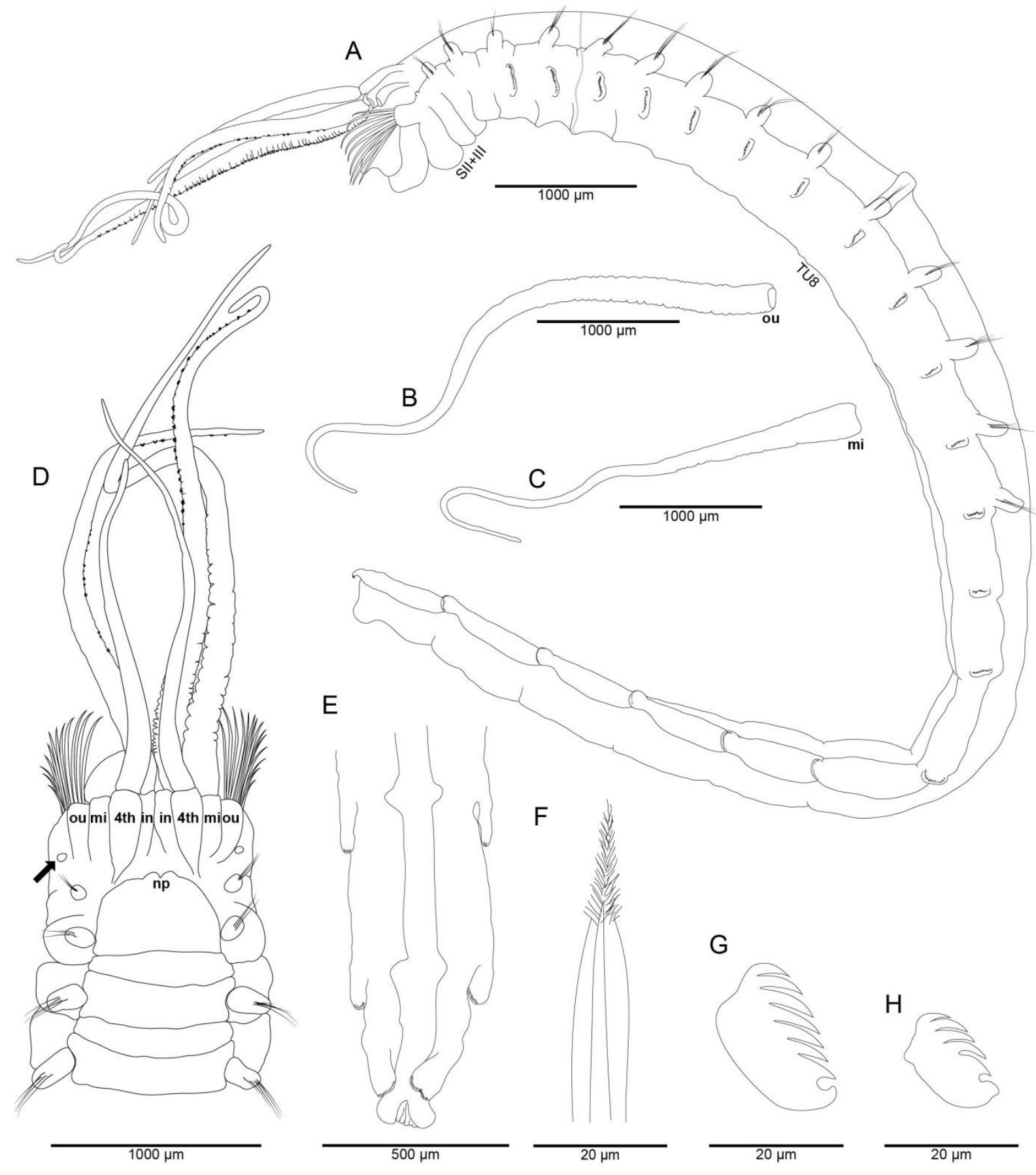

Figure 2. Anobothrus amourouxi sp. nov., holotype (MNHN-1561): (A) lateral view, specimen incomplete, showing fused SII+III; (B) deciduous branchia from outer (ou) pair; (C) deciduous branchia from middle (mi) pair; (D) anterior region, dorsal view, indicating reduced notopodia at fused segments II+III (arrow), nephridial papillae (np) and pairs of branchiae: (in) inner, (mi) middle, (ou) outer and (4th) fourth pair. Paratype (MNHN-1562): (E) pygidium, ventral view; (F) hirsute tips of notochaeta from modified eighth thoracic chaetiger (TU8). Paratype (MNHN1563): (G) uncinus from first thoracic uncinigers (TU1), lateral view; (H) uncinus from third abdominal unciniger (AU3), lateral view. 

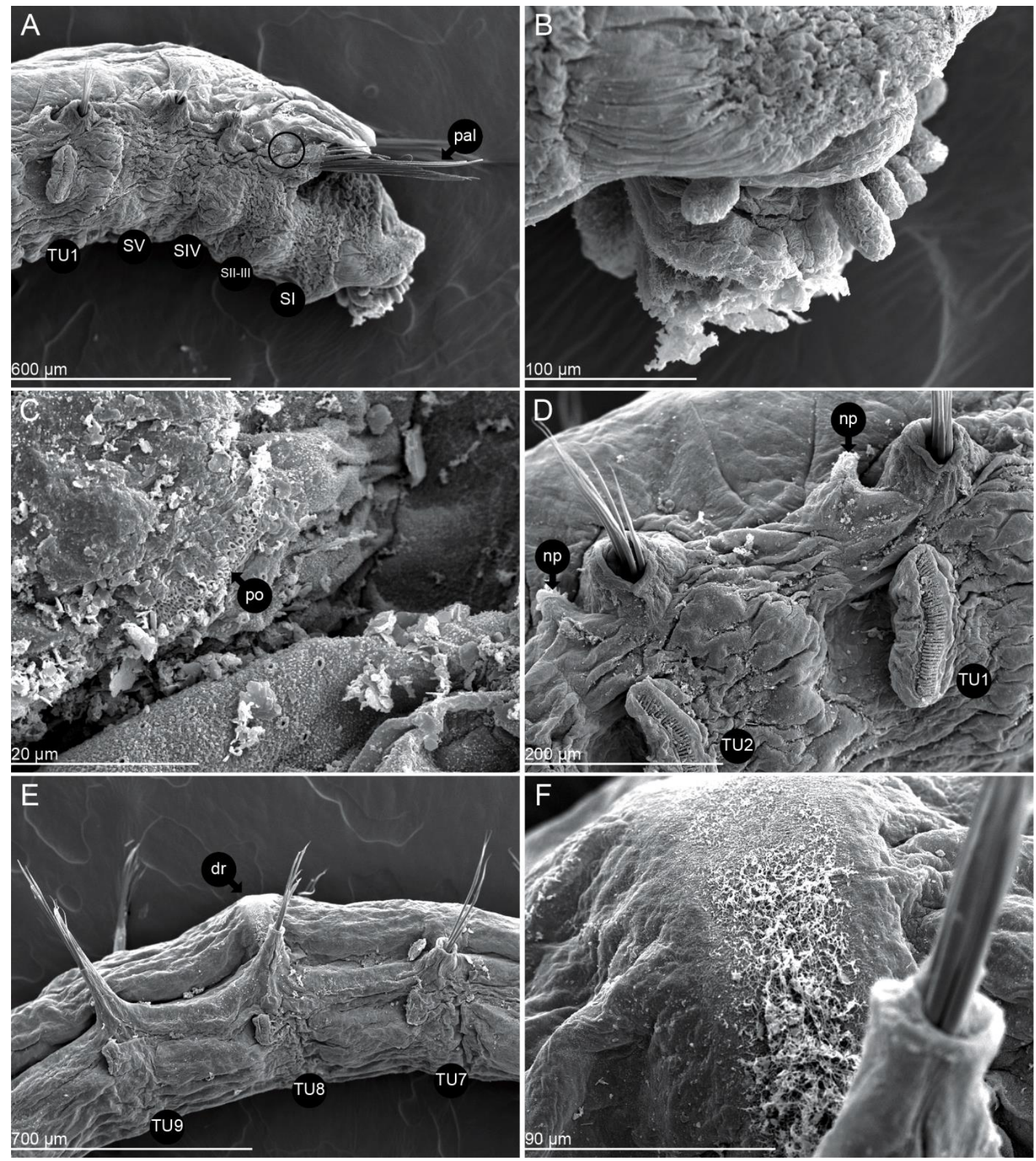

Figure 3. Anobothrus amourouxi sp. nov., paratype (MNCN-16.01/16071): (A) anterior end, right lateral view, showing first five thoracic segments (SI-SV), and first thoracic unciniger (TU1); reduced notopodia (encircled) at fused segments II+III behind the paleae (pal); (B) detail of prostomium and buccal tentacles, lateral view; (C) notopodia of fused segments II+III showing a row of pores (po); (D) TU1 and TU2 showing position of nephridial pores (np); (E) TU8 showing a transversal dorsal ridge (dr); (F) detail of dorsal ridge at TU8. 

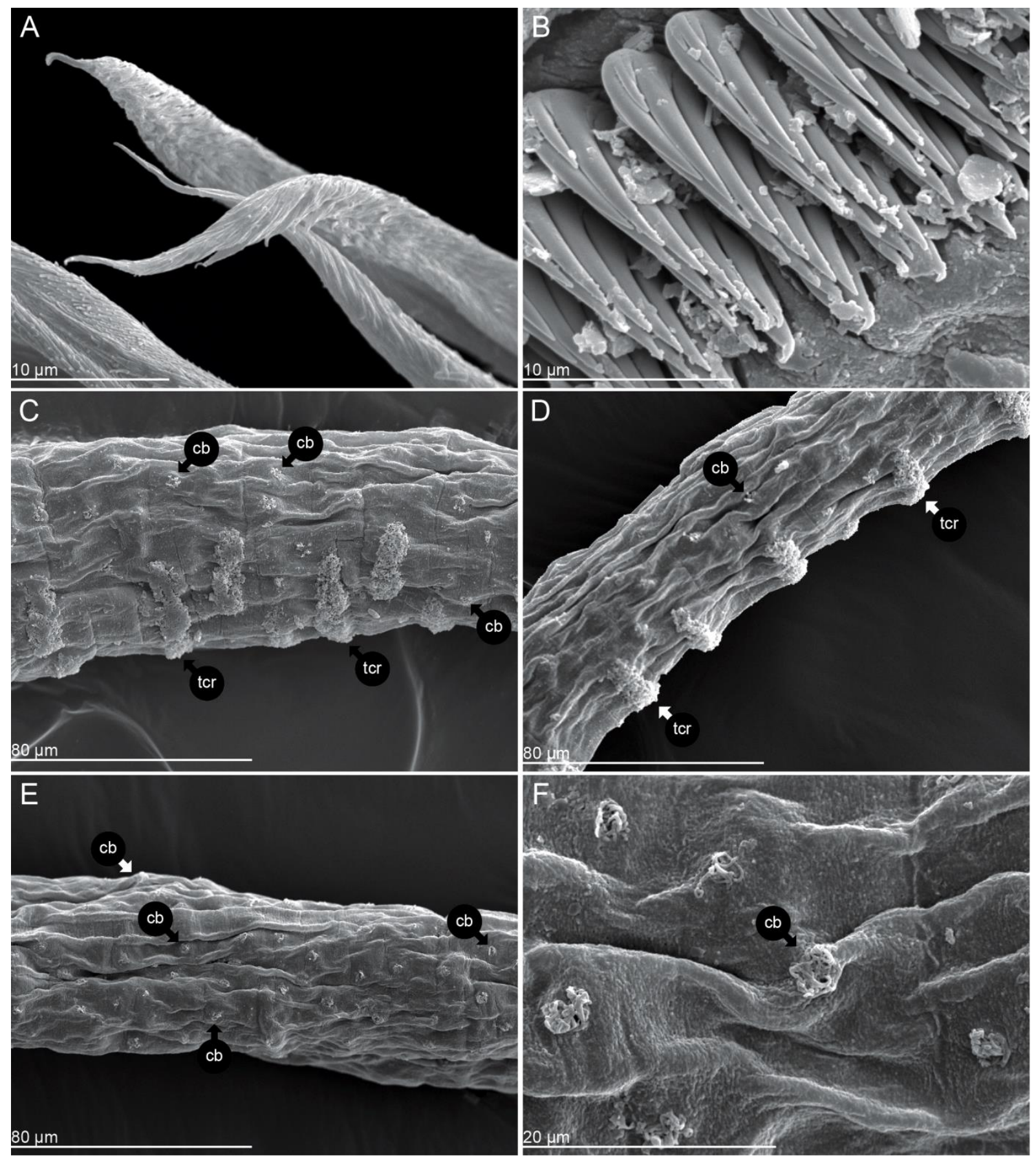

Figure 4. Anobothrus amourouxi sp. nov., paratype (MNCN-16.01/16071): (A) hirsute tips of T8 modified notochaetae; (B) thoracic uncini, upper-frontal view. Paratype (MNCN-16.01/16070): (C-D) basal and median zones of inner ciliated branchia showing the transversal ciliated ridges (tcr) and ciliated buttons (cb); (E-F) median and distal zones of smooth branchiae showing the ciliated buttons (cb). 


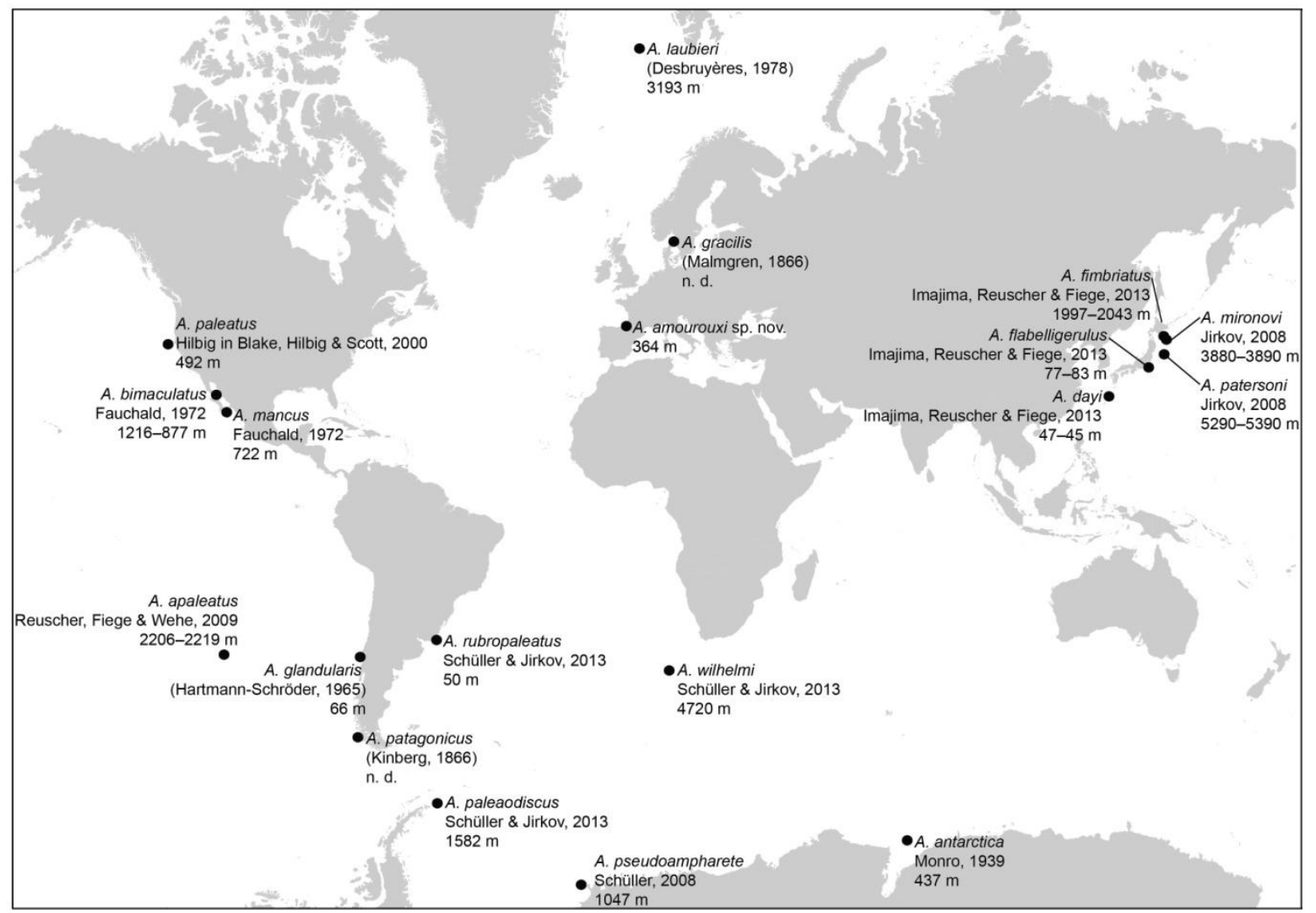

Fig. 5. World map showing location and depth of type locality of each currently considered valid species of Anobothrus.

KEY FOR IDENTIFICATION OF THE SPECIES OF THE GENUS ANOBOTHRUS IN THE WORLD

The following key accounts for the 18 species currently considered valid (Read, 2014) plus the new species here proposed. Described species are well distributed in the world ocean, but mainly concentrated in the southern hemisphere, NE Atlantic, Pacific coasts of North America and Japan. Nevertheless gaps still persist in the NW Atlantic, Indo-Malay Philippines archipelago and the coasts of Africa and Australia (Figure 5).

Five species were previously included in the genus Anobothrus but are currently considered invalid or excluded from this genus and thus excluded from the following key. Anobothrus nasuta (Ehlers, 1887), originally described in the genus Amphicteis, is supposed to belong to another genus (Jirkov, 2008; Schüller \& Jirkov, 2013). Anobothrus occidentalis Hartman, 1969 and Anobothrus trilobatus Hartman, 1969 were re-examined by Hilbig (2000) and are presently considered as belonging to the 
genera Sosanne and Eclysippe, respectively. Finally, Anobothrus nataliae Jirkov, 2008 and Anobothrus wakatakamaruae Imajima, 2009 are considered junior synonyms of Anobothrus paleatus (Imajima et al., 2013).

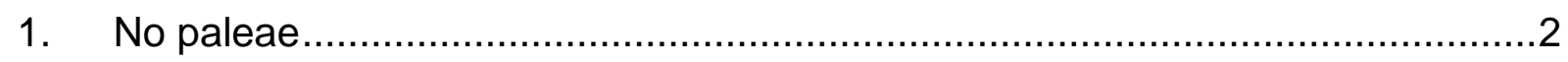

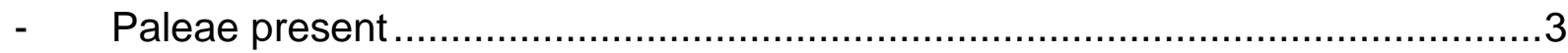

2. Modified notopodia with hirsute tips notochaetae

A. fimbriatus

- All notopodia without hirsute tips notochaetae

A. apaleatus

3. 3 pairs of branchiae 4

- 4 pairs of branchiae. 6

4. Modified notopodia on TU8 .5

- $\quad$ Modified notopodia on TU9 A. flabelligerulus

5. Notochaetae present on fused segments II- III, prostomium Ampharete-type, branchiae forming transversal line

A. laubieri

- Notochaetae absent on fused segments II-III, prostomium conical, wide gap between groups of branchiae

A. dayi

6. Modified notopodia on TU6

A. bimaculatus 
- $\quad$ Modified notopodia on TU7

A. mancus

- $\quad$ Modified notopodia on TU8 .7

- $\quad$ Modified notopodia on TU9

A. paleatus

7. Circular band on TU1

A. patagonicus

- $\quad$ Circular band on TU2 (modified notochaetae without hirsute tips) 8

- Circular band on TU3

8. Paleae colourless, fine, with base slimmer than (or equal to) most developed notochaetae, outer pairs of branchiae distinctly narrower than inner, 12-13 AU .. A. wilhelmi

- Paleae reddish, stout, with base stouter than most developed notochaetae, branchiae with almost the same diameter, $13 \mathrm{AU}$ A. rubropaleatus

9. Modified notopodia without notochaetae with hirsute tips 10

Only the modified notopodia with notochaetae with hirsute tips .11

- $\quad$ All notopodia with notochaetae with hirsute tips

A. gracilis

10. 3 teeth on uncini from TU1 (lateral view), paleae abruptly tapering to delicate tip A. pseudoampharete

- $\quad$ 8-9 teeth on uncini from TU1 (lateral view), diameter of all branchiophores more or less equal, less than 10 paleae, very conspicuous stout and long paleae 
- 5 teeth on uncini from TU1 (lateral view), fourth pair of branchiophores two times slimmer and shorter than others reduced and their branchiostyles many times shorter than others, paleae longer than best-developed notochaeta, gradually tapering.

A. patersoni

- 5 teeth on uncini from TU1 (lateral view), inner and middle pairs of branchiophores shorter and slimmer than others

A. mironovi

11. 6 teeth on uncini from TU1 (lateral view), surface of branchiostyle smooth, thoracic arrangement (fused SII-III with paleae from SII and without notochaetae from SIII)

A. glandularis

- 4-5 teeth on uncini from TU1 (lateral view), surface of all branchiostyles papillated, thoracic arrangement (fused SII-III with paleae from SII and notochaetae from SIII)

A. antarctica

- 6-7 teeth on uncini from TU1 (lateral view), surface of inner pair of branchiostyle with transversal ciliated ridges, thoracic arrangement (fused SII-III with paleae from SII and with reduced notopodia without notochaetae from SIII) A. amourouxisp. nov. 
The authors would like to thank the crew members of the R/V Côtes de la Manche (CNRS-INSU) and all people involved in the field sampling and sample processing, especially A. Roméro-Ramirez, O. Maire and M. Richard. We are very grateful to A. Grémare and B. Deflandre, coordinators of the BIOMIN Project. Thanks are also due to A. Castro and C. Sueiro (SAIN, UDC) who assisted with the preparation of specimens and the use of the SEM.

FINANCIAL SUPPORT

This work was partly funded by the French EC2CO-PNEC and LEFECYBER programmes through the BIOMIN project. It is part of the $\mathrm{PhD}$ Thesis of $\mathrm{P}$. Bonifácio who was funded by the "Agence de l'Eau Corse-Méditerranée" (convention n²010 0871), the "Agence des Aires Marines Protégées" (Marché N²009-AAMP-16; Lot N9; ASCONIT/GIS Posidonie), LECOB (UMR CNRS - UPMC) and EPOC (UMR CNRS - Université Bordeaux 1).

REFERENCES

Aguirrezabalaga F. and Carrera-Parra L. (2006) Lumbrineridae (Polychaeta) from the Capbreton Canyon (Bay of Biscay, NE Atlantic) with the description of two new species. Scientia Marina 70(S3), 17-25.

Aguirrezabalaga F. and Ceberio A. (2003) Dorvilleidae (Polychaeta) from the Capbreton Canyon (Bay of Biscay, NE Atlantic) with the description of Pettiboneia sanmartini sp. nov. Cahiers de Biologie Marine 44, 41-48.

Aguirrezabalaga F. and Ceberio A. (2005a) Sphaerodoropsis amoureuxi and S. stellifer, two new species of Sphaerodoridae (Polychaeta) from the Capbreton Canyon (Bay of Biscay, NE Atlantic). Cahiers de Biologie Marine 46, 9-20.

Aguirrezabalaga F. and Ceberio A. (2005b) Spionidae (Annelida: Polychaeta) from the Capbreton Canyon (Bay of Biscay, NE Atlantic) with descriptions of a new genus and three new species. Marine Biology Research 1, 267-280. 
Aguirrezabalaga F. and Ceberio A. (2006) Flabelligena gascognensis sp. nov. (Polychaeta: Acrocirridae), a new species from the Capbreton Canyon (Bay of Biscay, NE Atlantic). Scientia Marina 70(S1), 141-147.

Aguirrezabalaga F., Ceberio A. and Fiege D. (2001) Octomagelona bizkaiensis (Polychaeta: Magelonidae) a new genus and species from the Capbreton Canyon (Bay of Biscay, north-east Atlantic). Journal of the Marine Biological Association of the United Kingdom 81, 221-224.

Aguirrezabalaga F., Ceberio A. and Paxton H. (2002) Onuphidae (Polychaeta) from the Capbreton Canyon (Bay of Biscay, NE Atlantic) with the description of Paradiopatra capbretonensis sp. nov. Steenstrupia 27, 19-28.

Aguirrezabalaga F. and Gil J. (2009) Paraonidae (Polychaeta) from the Capbreton Canyon (Bay of Biscay, NE Atlantic) with the description of eight new species. Scientia Marina 73, 631-666.

Aguirrezabalaga F. and Parapar J. (2014) Deep-sea Ampharetidae (Polychaeta) from Capbreton Canyon (north-east Atlantic) with the description of a new species. Journal of the Marine Biological Association of the United Kingdom 94, 947-967.

Böggemann M. (2009) Polychaetes (Annelida) of the abyssal SE Atlantic. Organisms, Diversity and Evolution 9, 251-428.

Desbruyères D. (1978) Melythasides laubieri gen. sp. nov. Ampharetidae (Annélides Polychètes sédentaires) abyssal de la mer de Norvège. Bulletin du Muséum National d'Histoire Naturelle, Paris $3^{\mathrm{e}}$ sér., 353(514), 231-238.

Ehlers E. (1887) Florida-Anneliden (XXXI. Report on the Annelids). Reports on the results of dredging, under the Direction of L.F. Pourtalès, during the years 1868-1870, and of Alexander Agassiz, in the Gulf of Mexico (1877-78), and in the Caribbean Sea (187879), in the U.S. coast survey steamer "Blake". Memoirs of the Museum of Comparative Zoölogy at Harvard College 15, 1-335.

Fauchald K. (1972) Benthic polychaetous annelids from deep water off western Mexico and adjacent areas in the eastern Pacific Ocean. Allan Hancock Monographs in Marine Biology 7, 1-575.

Gaudin M., Mulder T., Cirac P., Berné S. and Imbert P. (2006) Past and present sedimentary activity in the Capbreton Canyon, southern Bay of Biscay. Geo-Marine Letters 26, 331-345.

Hartman O. (1967) Polychaetous annelids collected by the USNS Eltanin and Staten Island cruises, chiefly from Antarctic seas. Allan Hancock Monographs in Marine Biology 2, 1387.

Hartman O. (1969) Atlas of the sedentariate polychaetous annelids from California. Allan Hancock Foundation, University of Southern California, Los Angeles.

Hartmann-Schröder G. (1965) Zur Kenntnis des Sublitorals der chilenischen Küste unter besonderer Berücksichtigung der Polychaeten und Ostracoden. Mitteilungen aus dem Hamburgischen Zoologischen Museum und Institut 62, 1-384.

Hilbig B. (2000) Chapter 8. Family Ampharetidae Malmgren, 1867. In Blake J., Hilbig B. and Scott P. (eds) Taxonomic atlas of the benthic fauna of the Santa Maria Basin and the 
Western Santa Barbara Channel. Vol. 7. Santa Barbara, CA: Santa Barbara Museum of Natural History, pp. 169-230.

Imajima M. (2009) Deep-sea benthic polychaetes off Pacific coast of the northern Honshu, Japan. In Fujita T. (ed) Deep-sea fauna and pollutants off Pacific coast of northern Japan. National Museum of Nature and Science Monographs 39, 39-192.

Imajima M., Reuscher M.G. and Fiege D. (2013) Ampharetidae (Annelida: Polychaeta) from Japan. Part II: Genera with elevated and modified notopodia. Zootaxa 3647, 137-166.

Jirkov I.A. (2008) Revision of Ampharetidae (Polychaeta) with modified thoracic notopodia. Invertebrate Zoology 5, 111-132.

Jirkov I.A. (2011) Discussion of taxonomic characters and classification of Ampharetidae (Polychaeta). Italian Journal of Zoology 78, Suppl 1, 78-94.

Kinberg J.G.H. (1866) Annulata nova. Öfversigt af Kongl. Vetenskaps-Akademiens Förhandlingar 23, 97-103.

Laubier L. (1985) Le programme BIOGAS. In Laubier L. and Monniot C. (eds) Peuplements profonds du Golfe de Gascogne. Paris: IFREMER, pp. 13-23.

Levinsen G.M.R. (1884) Systematisk-geografisk Oversigt over de nordiske Annulata, Gephyrea, Chaetognathi og Balanoglossi. 2. Videnskabelige Meddelelser Dansk Naturhistorisk Forening 1883, 92-350.

Malmgren A.J. (1866) Nordiska Hafs-Annulater. Öfversigt af Kongl. VetenskapsAkademiens Förhandlingar 22, 355-410.

Mazières A., Gillet H., Castelle B., Mulder T., Guyot C., Garlan T. and Mallet C. (2014) High-resolution morphobathymetric analysis and evolution of Capbreton submarine canyon head (Southeast Bay of Biscay-French Atlantic Coast) over the last decade using descriptive and numerical modeling. Marine Geology 351, 1-12.

Monro C.C.A. (1939) Polychaeta. Antarctic Research Expedition Reports 4(4), 87-156.

Nuñez J., Aguirrezabalaga F. and Ceberio A. (2000) Species of Nereididae from the Capbreton Canyon (Bay of Biscay, northeast Atlantic). Bulletin of Marine Science 67, 25-37.

Parapar J., Helgason G.V., Jirkov I. and Moreira J. (2014) Diversity and taxonomy of Ampharetidae (Annelida, Polychaeta) from Icelandic waters. Polish Polar Research, 35(2):311-340.

Pascual A., Cearreta A., Rodríguez-Lázaro J. and Uriarte, A. (2004) Chapter 3 Geology and Palaeoceanography. In Borja A. and Collins M. (eds) Oceanography and marine environment of the Basque Country. Amsterdam: Elsevier, pp. 53-73.

Petus C., Marieu V., Novoa S., Chust G., Bruneau N. and Froidefond J.M. (2014) Monitoring spatio-temporal variability of the Adour River turbid plume (Bay of Biscay, France) with MODIS 250-m imagery. Continental Shelf Research 74, 35-49.

Rallo A., García-Arberas L. and Isasi I. (1993) Fauna macrobéntica de los fondos del cañón de Capbretón: análisis faunístico de poliquetos, crustáceos y cnidarios y 
caracterización de puntos de muestro según estos descriptores. Cahiers de Biologie Marine 35, 69-90.

Read G. (2014) Anobothrus Levinsen, 1884. In Read G. and Fauchald K. (eds) World Polychaeta database. Accessed through: World Register of Marine Species at http://www.marinespecies.org/aphia.php?p=taxdetails\&id=129158 on 2014-09-16.

Reuscher M., Fiege D. and Wehe T. (2009) Four new species of Ampharetidae (Annelida: Polychaeta) from Pacific hot vents and cold seeps, with a key and synoptic table of characters for all genera. Zootaxa 2191, 1-40.

San Martín G., Ceberio A. and Aguirrezabalaga F. (1996) Exogone species (Polychaeta: Syllidae: Exogoninae) from the Capbreton Canyon (Bay of Biscay, NE Atlantic). Cahiers de Biologie Marine 37, 249-258.

Schüller M. (2008) New polychaete species collected during the expeditions ANDEEP I, II, and III to the deep Atlantic sector of the Southern Ocean in the austral summers 2002 and 2005 - Ampharetidae, Opheliidae, and Scalibregmatidae. Zootaxa 1705, 51-68.

Schüller M. and Jirkov I.A. (2013) New Ampharetidae (Polychaeta) from the deep Southern Ocean and shallow Patagonian waters. Zootaxa 3692, 204-23. 